\title{
A beach-ridge progradation complex reflecting periodical sea-level and climate variability during the Holocene (Gulf of Almería, Western Mediterranean)
}

\author{
José Luis Goy ${ }^{\mathrm{a}}$, Cari Zazo ${ }^{\mathrm{b}, *}$, Cristino J. Dabrio ${ }^{\mathrm{c}}$ \\ ${ }^{a}$ Departamento de Geología, Facultad de Ciencias, Universidad de Salamanca, 37008 Salamanca, Spain \\ ${ }^{\mathrm{b}}$ Departamento de Geología, Museo Nacional de Ciencias Naturales, CSIC, Jose Gutierrez Abascal, 2, 28006 Madrid, Spain \\ ${ }^{\mathrm{c}}$ Departamento de Estratigrafía and Instituto de Geología Económica, CSIC, Universidad Complutense, 28040 Madrid, Spain
}

Received 1 September 2000; received in revised form 1 July 2001; accepted 15 July 2002

\begin{abstract}
Detailed mapping based on aerial photographs at various scales, analysis of morpho-sedimentary units, and radiocarbon dating of the prograding beach-ridge complex of Campo de Dalías (Almería) allow the differentiation of six prograding units. These are called: $\mathrm{H}_{1}, 7400-6000$ cal BP; $\mathrm{H}_{2}, 5400-4200$ cal BP; $\mathrm{H}_{3}, 4200-3000$ cal BP; $\mathrm{H}_{4}, 2700-1900$ cal BP; $\mathrm{H}_{5}, 1900-$ $1100 \mathrm{cal} \mathrm{BP}$; and $\mathrm{H}_{6}, 500$ cal BP-Present. $\mathrm{H}$-units are deposited during periods of high relative sea level and increased sediment input to the coast. They are bounded by large swales or erosional surfaces associated with lower sea levels and reduced input of sediment to the coast; these correspond to short periods of increased aridity inside the general arid trend recorded in the Western Mediterranean since $5.4 \mathrm{ka}$. Changes in the flux of Atlantic superficial waters into the Mediterranean Sea, and relative strength of the W/SW winds account for the recorded oscillations of relative sea level.

We deduce a decadal periodicity for the deposition of a beach ridge and the adjacent swale, and suggest that it is related to fluctuations of the North Atlantic Oscillation (NAO) index and to variations of solar activity. The duration of H-units shows a quasi-millennial periodicity punctuated by short (hundred years) episodes of reduced progradation or erosion representing events of increased aridity likely to be related to Bond's Holocene cold events.
\end{abstract}

Keywords: Sea-level changes; Climate; Winds patterns; Radiometric dating; NAO

\section{Introduction}

The well-exposed, complex system of prograding beach ridges in the coastal plain near Roquetas (Fig. 1) has been repeatedly cited as the best on-land example in the Western Mediterranean with a great potential interest for correlation with the usually

\footnotetext{
* Corresponding author. Fax: +33-34-1-5644740.

E-mail address: mcnzc65@mncn.csic.es (C. Zazo).
}

undated, high-resolution, seismic surveys on the shallow shelf, after Goy et al. (1986a) and Zazo et al. (1994) used ${ }^{14} \mathrm{C}$ dating to distinguish several prograding units of Holocene $(\mathrm{H})$ age. These units, commonly referred to as $\mathrm{H}_{1}$ to $\mathrm{H}_{4}$ units, began to form following the Holocene sea-level maximum in the Spanish south and southeastern coasts, at ca. $7000 \mathrm{cal} \mathrm{BP}$ (Goy et al., 1986a; Zazo et al., 1994, 1996; Somoza et al., 1998; Dabrio et al., 2000). Oscillations of sea-level related with changing incursions of Atlantic superficial waters 


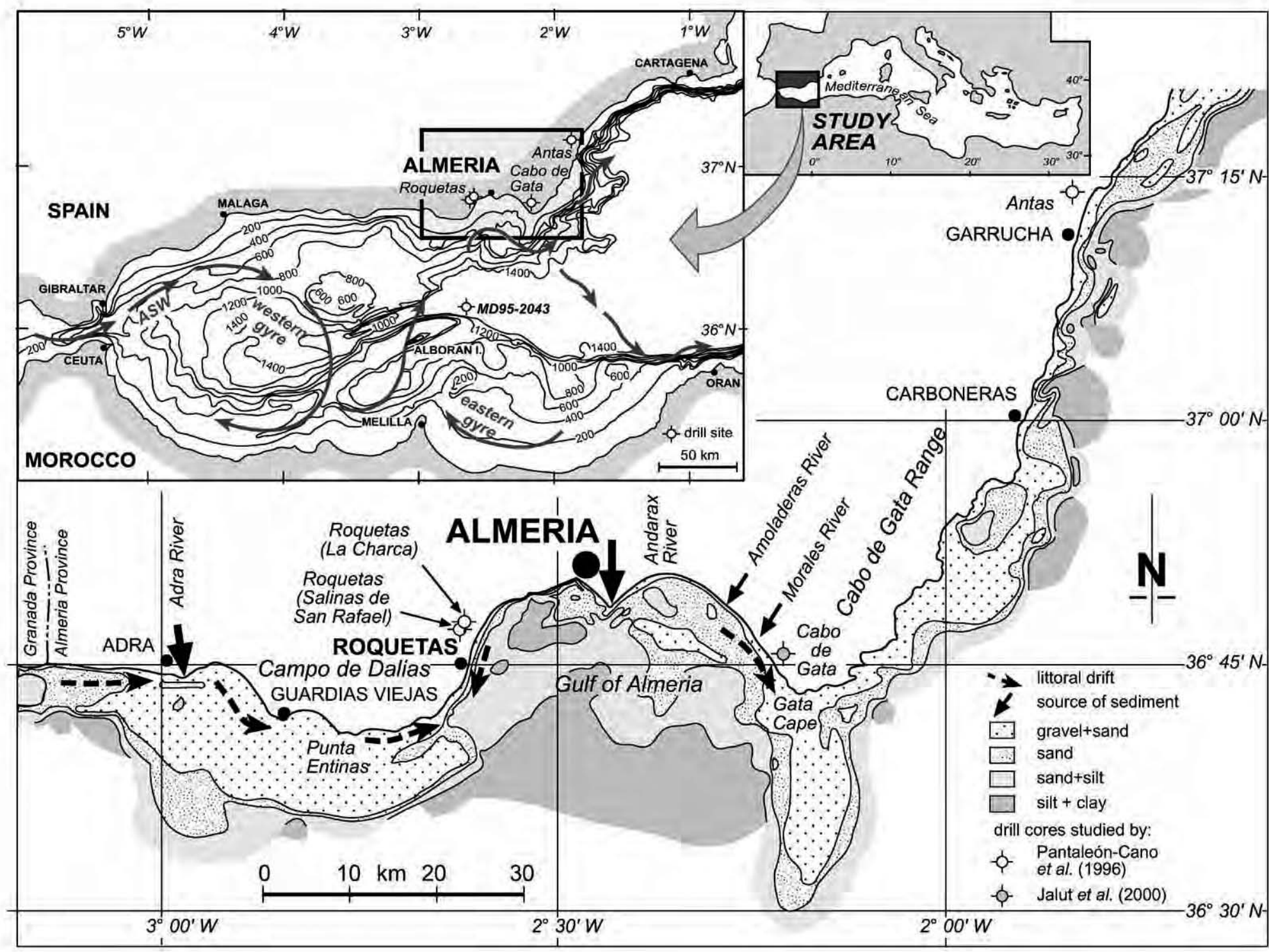


(ASW) into the Mediterranean Sea, and some periodicity in the genesis of beach ridges related to fluctuations of solar activity were pointed out by Zazo et al. (1994) and Goy et al. (1986a), respectively. Vignudelli et al. (1999) demonstrated the influence of North Atlantic Oscillation (NAO), an interannual to decadal coupled ocean-atmospheric oscillation. This influences the climate from North America to Siberia and from Greenland to the Equator, and perhaps beyond (Hurrell, 1996; Sarachik and Alverson, 2000) on the circulation of the Western Mediterranean Sea.

More recently, Rodríguez-Ramírez et al. (2000) related the deposition of beach-ridge and swale systems in the Atlantic façade of the Iberian Peninsula to periodical fluctuations of the NAO index and the solar activity. Cacho et al. (2001) found six short events of sea surface temperature (SST) that interrupt the general cooling trend through the Holocene in the Alborán Sea off Almería and related them to some of the cold events recognised by Bond et al. (1997) in the North Atlantic. Two (the more recent) of the events recorded in the Alborán occurred during the deposition of the Roquetas beach-ridge complex. The dynamic factors forcing the progradation of the Roquetas coastal plain were only partially studied in previous papers, mostly because of the lack of trenches that allowed 3-D observations and adequate sampling for radiocarbon dating. Massive building of holiday resorts in the area in recent years allowed the use of many trenches excavated for foundations for observation of the internal structure and stratigraphical architecture of ridges and swales.

The aims of this paper are thus to integrate the recently available trench data with radiometric dating of new samples from the area in order to: (i) analyse the genesis of beach-ridge and swale systems, and the mechanisms involved in the progradation or erosion of the coastal plain; (ii) relate the configuration of the beach ridges and swales with relative changes of sea level, and to yield figures of the magnitudes involved in such changes; (iii) investigate the relations of these parameters with climate changes in the study area and with the land-ocean-atmosphere teleconnections in the Atlantic-Mediterranean linkage area and (iv) investigate how the cyclic climate instability recorded in ice and ocean cores is recorded on land.

\section{Present-day climatic conditions and coastal dynamics}

The Mediterranean climate is markedly seasonal, with cool winters and hot, dry summers: mean temperature in Almería is $18{ }^{\circ} \mathrm{C}$ (average: $13{ }^{\circ} \mathrm{C}$ in January and $24{ }^{\circ} \mathrm{C}$ in July). The area is located in the subtropical high-pressure belt and experiences the influence of the Azores anticyclone, a long-lasting high-pressure cell in the NE Atlantic, particularly felt during the dry summer months. Rainfall of Atlantic origin occurs mainly at the onset and the end of the winter season (Anonymous, 1976; 1HM, 1983). Thus, most of the scarce rain in Almería (average 200-300 $\mathrm{mm}$ ) is of cyclonic origin and related to prominent contrasts of temperatures between land and sea.

Present excess evaporation in the Mediterranean Sea results in a two-layered flow at the Strait of Gibraltar: a surface inflow of less saline North Atlantic waters (NAW), and a deeper outflow of cooler, more saline Mediterranean outflow water (MOW). The most superficial part of the NAW, between 0 and $\sim 100 \mathrm{~m}$ is called Atlantic Surface Water (ASW). The surface circulation pattern in the Alborán Sea consists of two anticyclonic gyres (Fig. 1): a western one near Malaga, and the other more to the east, near Almería (Herburn and la Violette, 1990). This pattern and the velocity of the inflow respond to long-term changes of sea level and to the intensity of thermohaline circulation.

Analysis of satellite images over the last 15 years revealed four possible patterns of ASW gyres, but the two-gyre model, associated with high values of inflow velocity, is by far the most stable over the time period (Targarona et al., 1997). Westerly winds push the inflow velocity to a maximum and also force the western gyre to the east up to the meridian of Almería (Fig 1).

Fig. 1. Location map of the study area with drill sites cited in the text. The present distribution of sediment on the sea floor (Baena et al., 1982) indicates that the main source of sediment to the Campo de Dalías coast is the Adra River. The contribution of fluvial sources located eastwards of Almería City is negligible due to the prominent littoral drift to the southeast. Inset: synthetic physiographic map of the Western Mediterranean basins and the most stable model of gyres of the ASW inflow (modified from Targarona et al, 1997). MD95-2043 location of deep-sea core studied by Cacho et al. (2001). Contour lines in meters. 
Prevailing winds in the area blow from the west and east (the so-called Ponientes and Levantes, respectively) and usually persist for several days. The warm, moist westerly winds are particularly intense in autumn and winter. They induce major storms associated with low pressure over the Mediterranean, Easterly winds are generated in the eastern margin of the Azores anticyclone and predominate in spring and summer.

A large part of the southern coast of Spain that borders the Alborán Sea is oriented $\mathrm{E}-\mathrm{W}$, i.e., roughly parallel to the prevailing winds, a situation likely to favour longshore currents and littoral drift. In contrast, the Gulf of Almeria opening between the large, hilly headlands of Campo de Dalías and Cabo de Gata (Fig. 1) penetrates some kilometres to the north breaking this trend. Prevailing waves in the Gulf of Almeria reach the coast from the $\mathrm{W}-\mathrm{SW}$ and $\mathrm{E}-$ SE pushed by persistent winds that temporarily raise the waterline (wind setup) and increase the longshore transport. The W-SW winds coincide with "swell" conditions, with wave heights $1.5-2.5 \mathrm{~m}$, whereas the E-SE winds produce "sea" waves with heights usually $0.5-1 \mathrm{~m}$ (IHM, 1983). Strong winds magnify these figures.

The hilly headlands shelter parts of the gulf from the opposite-blowing winds, creating traps of sediment. Along the eastem side of the gulf, strong westerly winds blowing for several days at a time induce transport to the E-SE. Easterly winds cause the same effect in the western side of the gulf, where Roquetas is situated. The coast of Almería is almost nontidal, with astronomical tidal ranges less than 0.3 $\mathrm{m}$, but meteorological tides related to wind setup exceed $1 \mathrm{~m}$ for periods of several days at a time, allowing larger wave runups and deposition of relatively high berms and beach crests with steep beach faces.

Most of the Holocene (and present) coast along the Gulf of Almería can be described as prograding, reflective gravelly beaches. Minor differences along the shore reflect local factors such as recent tectonic trends, amount and grain size of sediment input, and exposure to the prevailing winds and wavefronts.

Several ephemeral rivers flowing into the north (Andarax River) and eastern (Ramblas de las Amoladeras and Morales) coasts of the Gulf of Almeria supply abundant gravel and sand to the coastal zone, where longshore currents move them to the east, away from the Campo de Dalías.

In contrast, maps of present distribution of sediments on the sea floor (Baena et al., 1982) show evidence that most of the sediment off the coast of Campo de Dalías (and Roquetas coastal plain) is derived, via longshore transport, from the Adra River delta, some $7 \mathrm{~km}$ to the west (Fig. 1). A significant fraction was contributed by wave erosion (erosional transgression) of the tectonically uplifted last interglacial gravelly units that outcrop to the southwest of Roquetas, and resulted in a cliff $3-4 \mathrm{~m}$ high (Fig, 2). This source was active several thousand years after the maximum of the Holocene transgression. Eventually, the cliff was separated from the sea by newly deposited Holocene beach ridges and the supply ceased. Fluvial sediment input to the western side of the Gulf is negligible because recent tectonic uplift has diverted the local fluvial network to the endorheic Campo de Dalías (Goy et al., 1986b).

In summary, the Holocene coast of Campo de Dalías received only a very limited supply of (coarsegrained) sediment that was moved alongshore by littoral drift under opposing prevailing winds. The nontidal coast was very sensitive to oscillations of sea level, even at very small scales (decimetre scale), that seem to be related largely to local influences of the interchange of water masses through the Strait of Gibraltar under eustatic and climatic forcing.

\section{The beach-ridge complex of the Gulf of Almería}

\subsection{General features of the beach ridges}

The complex of beach ridges is best represented in the southern and eastern coasts of Campo de Dalías, between Roquetas and Guardias Viejas (Fig. 2). The Holocene coastal plain extends seawards of an erosional cliff cut into the last interglacial gravelly marine terraces that are affected by a $\mathrm{N} 140-160^{\circ} \mathrm{E}$ fault system (Goy and Zazo, 1986; Goy et aI, 1986b). Local tectonics and the previous coastal morphology favoured the formation of barriers and lagoons during the Holocene.

The term beach ridge is used in this paper to refer to relict strand plain ridges, presumably wave- or swash-built, that can be further exaggerated by wind 


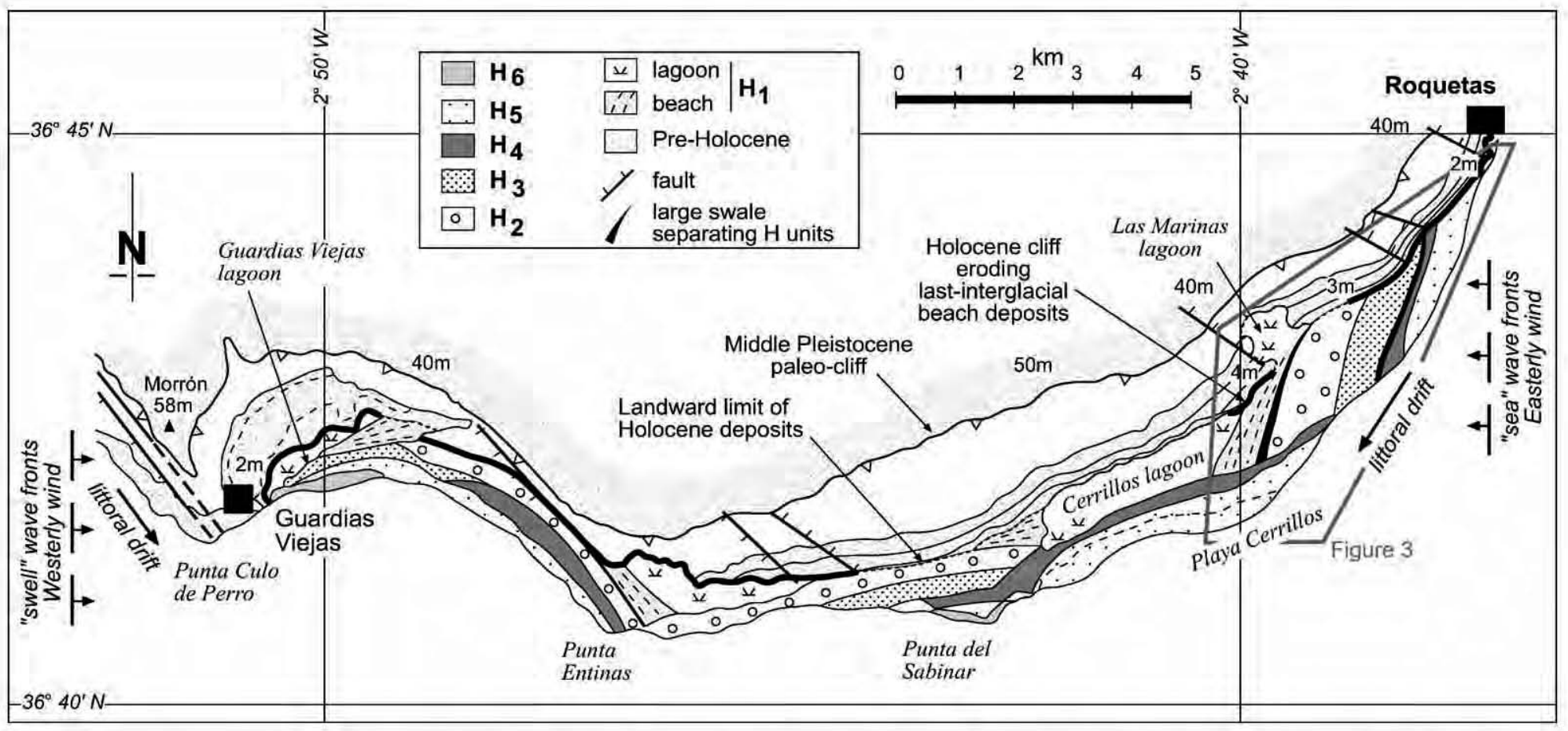

Fig. 2. Geological map of morpho-sedimentary Holocene units in the Campo de Dalías coast. Figures in the pre-Holocene deposits indicate elevations of paleo-cliffs. 
effects. This interpretation is supported by detailed facies analysis of the internal structure of the beach units. Tanner (1995) distinguished several genetic types of beach ridges and, after facies analysis of the internal structure and other indicators, stated that almost all beach ridges were deposited by waves and swash with alternatively high and low sea levels. Otvos (2000) produced a more complex list, although he paid less attention to the internal structures and the lateral arrangement of units in vertical sections. He considered that beach ridges of a proven wave-built origin may also serve as indicators of ancient higherthan-present sea levels.

Trenches dug at right angles to the mean shoreline in various sites of the Holocene Roquetas coastal plain allowed observation of lithology, internal structure, and lateral facies relationships. Trenches available during our field surveys were concentrated mostly in the areas near Las Marinas lagoon and south of Roquetas (Fig. 3).

The grain size of the Holocene beaches studied is coarse sand to fine gravel. Bivalve shells and bioclasts rarely exceed $15 \%$. The internal structure of the beach face consists of sets of parallel lamination gently inclined seaward (east). In a section normal to the shore, lamination shows a concave-upwards profile, with original dips up to $6-7^{\circ}$ in the topographically higher, landward side. The highest part of the beach face (berm) is marked by an accumulation of fine gravel that forms the nucleus of a new beach ridge.

The transition to the shoreface facies is marked by an accumulation of gravel that forms a decimetre-high (plunge) step, a feature commonly observed in the present beaches of this region. It is in this part where mollusc shells are more abundant, and was a preferred site for sampling shells, when it was exposed in trenches. The change from foreshore to shoreface facies is remarked by a decrease in the original dip. In some cases, the plunge-step has been preserved as planar cross-bedding pointing seaward, similar to that described by Zazo et al (1998).

The shoreface facies consist of wave-rippled and parallel-laminated medium to coarse sand with sparse burrowing. There are interbedded layers of gravel with parallel lamination and flat, erosional lower boundaries. The average original dip is less than $2^{\circ}$ to seaward.

\subsection{Units of beach ridges and progradation sequence}

The prograding beach-ridge complex was mapped using sets of aerial photographs taken in various years and at scales $1: 33,000$ and $1: 18,000$. The length, width and height of adjacent crests and the intervening swales tend to be more or less regular and permit grouping them into bundles, or entities having roughly the same magnitudes. In plan view, these features vary across the complex of crests more or less regularly. However, some of the swales are particularly wide and there are also surfaces that truncate one or more bundles of crests and eliminate some beach ridges from one side of the coastal plain to the other. These are common features in coastal plains around the world (Tanner, 1995). The prograding pattern observed in aerial photographs is also visible in vertical sections along trenches. This allows the study of the 3-D arrangements of units, which can be traced some distance laterally, at a right angle to the shoreline, as depicted schematically in Fig. 3.

Ridges that record beach progradation occur as couplets separated by a narrow intervening depression or swale. Adjacent couplets are separated by slightly wider swales. In turn, pairs of couplets are separated by still wider swales, easily recognisable in aerial photographs. It is interesting to note that the swale found every four sets is noticeably wider, resulting in a notable configuration of groups of sets. We have called this four-ridge pattern a "set" of beach ridges (Fig. 4). Observing the whole outcrop, we noted that the crests in a set tend to be better separated and the swales become wider in a southward direction, whereas in other cases, the size and trend is more homogeneous. According to this, we were able to separate two slightly different configurations of sets, and informally called them A and B (Fig. 4). Tanner (1995) used this set in a sense that is not very different than ours, and a system of sets that is equivalent to our units.

Using these features, we can distinguish six prograding units that, following our previous papers

Fig. 3. Schematic map of the Roquetas-Playa Cerrillos sector with location of samples used for radiometric dating (note that italics indicate calibrated ages) and geological sketches drawn in trenches, with vertical scale exaggerated. 





TWO CONFIGURATIONS OF BEACH RIDGES WITH A DECADAL PERIODICITY

\section{Configuration $\mathrm{A}$}

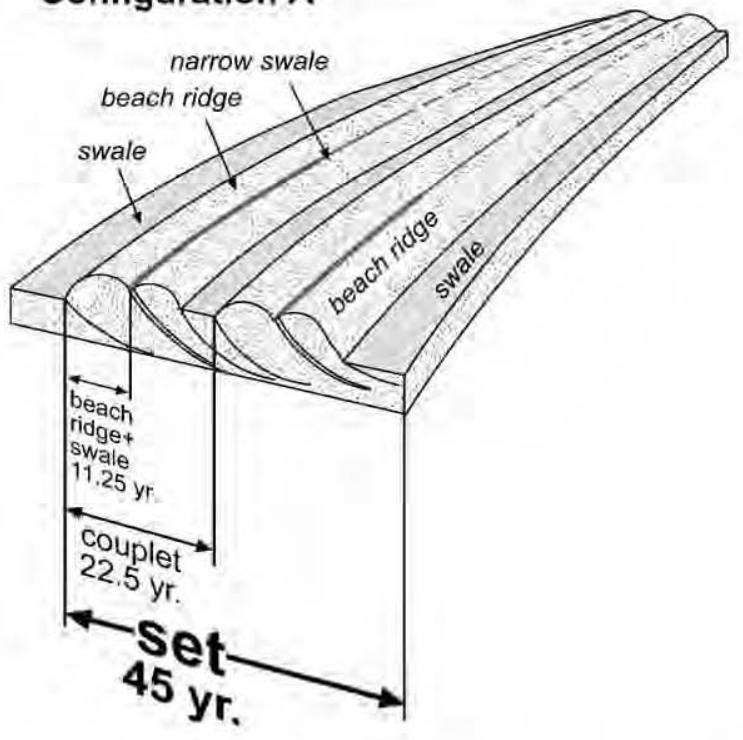

Configuration B

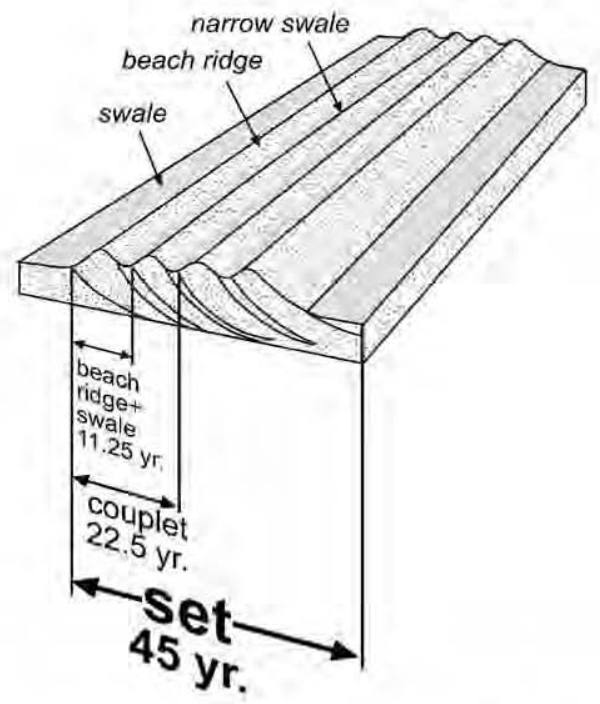

Fig. 4. A simple sketch illustrating the two basic configurations of beach-ridges and swales informally named $\mathrm{A}$ and $\mathrm{B}$ and the decadal periodicity involved in their genesis.

(e.g. Zazo et al., 1994; Goy et al., 1998), we have named $\mathrm{H}_{1}$ to $\mathrm{H}_{6}$ (Fig. 3). $\mathrm{H}$ reads for Holocene, and subindexes $1-6$ refer to progressively younger ages.
H-units can be defined as groups (bundles) of sets distinguished from the adjacent by changes of set configuration (namely height and width of the beachridge/swale couplets), large swales or erosional surfaces.

We assume that changes in size and amplitude of the ridges and swales prove that the general trend of progradation was not homogeneous. Instead, it experienced changes, and even reversions, that are presented below.

Unit $\mathrm{H}_{1}$ is largely attached to the erosional cliff cut into the raised gravelly marine terraces of the last interglacial age (Fig. 2). It is, at present, badly degraded by human impact, preventing a reliable counting of the number and elevation of beach ridges deposited in this episode. The few better-preserved ridges seem to be of very low relief, with topographic elevations close to the present mean sea level (MSL). According to our reconstruction using aerial photographs, the prograding $\mathrm{H}_{1}$ ridges formed cuspate bars that enclosed coastal lagoons. In the best-preserved places of the eastern Campo de Dalías, near Las Marinas, the unit ends in a large swale.

The first ridges of Unit $\mathrm{H}_{2}$ onlap the large limiting swale, rising approximately $2 \mathrm{~m}$ above it (Fig. 3). They can be traced laterally to a layer (elevation +2 $m$ MSL) of palaeo-lagoon deposits that occur in the inner shores of Las Marinas lagoon, containing a very poor fauna of Ostrea and Cerithium shells.

A trench dug in the boundary area exposed an erosional surface separating $\mathrm{H}_{1}$ and $\mathrm{H}_{2}$, and the onlap of the first swash bars that migrated to landwards at the base of $\mathrm{H}_{2}$ (Fig. 3). Radiocarbon dating of samples collected above and below this surface confirmed the difference in ages (Table 1, Fig. 3). The erosional event is neatly exposed in the southern part near Punta Entinas, where it destroyed a whole segment of the $\mathrm{H}_{1}$ beach ridges (Figs. 2 and 5 ).

Unit $\mathrm{H}_{2}$ consists of beach ridges with set configuration " $A$ " (Fig. 4), but is divided into two parts. In the older, inner part, ridges and swales are wide and crests topographically high ( $\geq 2 \mathrm{~m}$ MSL), with a preserved total of five sets of beach ridges. Ridges and swales in the younger, outer part are narrower and topographically lower $(1.5 \mathrm{~m})$, with a preserved total of 12 sets of beach ridges.

The boundary between units $\mathrm{H}_{2}$ and $\mathrm{H}_{3}$ is well marked in aerial photographs by a highly visible, 
Table 1

Database of ${ }^{14} \mathrm{C}$ samples collected in trenches, and laboratory results

\begin{tabular}{|c|c|c|c|c|c|c|c|c|}
\hline $\begin{array}{l}\text { Laboratory } \\
\text { code }\end{array}$ & $\begin{array}{l}\text { Sample } \\
\text { code }\end{array}$ & $\begin{array}{l}\text { CRA } \\
\text { (years BP) }\end{array}$ & Error & $\begin{array}{l}\delta^{13} \mathrm{C} \% 0 \\
(\mathrm{PDB})\end{array}$ & Material & Cal BP & $\begin{array}{l}\text { Interval, } \\
\text { cal BP }\end{array}$ & Reference \\
\hline UQ-1133 & R-8 & 6885 & 100 & 2.1 & Glycymeris shell & 7410 & $7475-7300$ & a \\
\hline UQ-1140 & $\mathrm{R}-10$ & 2585 & 100 & & Glycymeris shell & 2290 & $2345-2125$ & a \\
\hline UQ-1115 & R-9 & 2385 & 100 & 2.0 & Glycymeris shell & 1995 & $2125-1885$ & \\
\hline UQ-1114 & $R-x$ & 5000 & 100 & 2.8 & Cerithium shell & 5315 & $5460-5260$ & \\
\hline GX-21770 & $\mathrm{RO}-95-2$ & 2495 & 75 & 1.3 & Glycymeris shell & 2140 & $2280-2050$ & \\
\hline GX-22227 & RO-96-1 & 1940 & 85 & 1.5 & Glycymeris shell & 1500 & $1580-1390$ & \\
\hline GX-22228 & $\mathrm{RO}-96-2$ & 1980 & 80 & 1.5 & Glycymeris shell & 1530 & $1620-1435$ & \\
\hline GX-22229 & RO- $96-3$ & 5885 & 115 & 1.5 & Glycymeris shell & 6285 & $6405-6185$ & \\
\hline GX-22230 & $\mathrm{RO}-96-4$ & 4735 & 105 & 0.8 & Glycymeris shell & 4960 & $5130-4830$ & \\
\hline GX-22235 & RO-96-9 & 6000 & 175 & 1.8 & Glycymeris shell & 6400 & $6620-6255$ & \\
\hline
\end{tabular}

UQ: University of Quebec at Montreal, Canada; GX: Geochron Lab., MA, USA; Lv: Louvain-la-Neuve, Belgium. CRA: Conventional Radiocarbon Ages. Cal BP ages using CALIB 3.0 Program (Stuiver and Reimer, 1993).

a Sample values incorporated from Goy et al. (1986a).

slightly wider swale and a change in set configuration, to the thin and laterally continuous type " $\mathrm{B}$ " beachridge sets with an average height of $1 \mathrm{~m}$ (Fig. 4). However, the boundary is obscure in field surveys. Inside the otherwise-homogeneous $\mathrm{H}_{3}$, a noticeable erosional surface truncates several beach ridges eliminating a significant part of the exposed sedimentary record, as confirmed by radiocarbon dating. There are 8.5 preserved sets of beach ridges before the erosional surface and 1.5 between it and the swale marking the limit with the younger Unit $\mathrm{H}_{4}$.

Unit $\mathrm{H}_{4}$ is separated from $\mathrm{H}_{3}$ by a large swale in the eastern side (south Roquetas). 3-D geometry of units observed in a trench does not show prominent erosion (Fig. 3). In contrast, major erosion occurred in the southern sector (Playa Cerrillos) as evidenced by a change of the direction of progradation and an erosional escarpment cutting across units $\mathrm{H}_{1}$ and $\mathrm{H}_{2}$.

Sets of beach ridges in Unit $\mathrm{H}_{4}$ belong to configuration "B". In the northeastern part, only one set of beach ridges is observed at the surface, but trenches showed that deposits of $\mathrm{H}_{4}$ extend seaward below the erosional surface and the younger $\mathrm{H}_{5}$, as confirmed by radiocarbon ages (Table $\mathrm{I}$ ). This implies that erosion of $\mathrm{H}_{4}$ did not proceed too far below MSL (Fig. 3). At least 12 sets of beach ridges have been preserved in this part, with average ridge heights ranging from $1 \mathrm{~m}$ at the beginning to $1.5 \mathrm{~m}$ by the end of this unit. Trenches were not available in the Playa Cerrillos area for observation of the 3-D internal structures and the extent of the erosional processes, and our data come from geomorphological observations on aerial photographs.

Unit $\mathrm{H}_{5}$ includes 12 sets of beach ridges with configuration $\mathrm{A}$. The limit with $\mathrm{H}_{4}$ is an erosional surface. The crests of the first two sets are topographically more elevated (ridge height: $2 \mathrm{~m}$ ) than the rest (average ridge height: $1-1.2 \mathrm{~m}$ ). Trench observations show that the oldest (more inland) $\mathrm{H}_{5}$ deposits correspond to proximal foreshore facies that rest directly on top of the $\mathrm{H}_{4}$ upper-shoreface facies (Fig. 3). Unit $\mathrm{H}_{6}$ is limited by an erosional surface that cuts across $\mathrm{H}_{\mathrm{I}}$ to $\mathrm{H}_{5}$. This unit is the youngest recognised and it is poorly represented (Fig. 2).

\section{Results and discussion}

\subsection{Origin of beach ridges}

The beach ridges in the Roquetas coastal plain were formed by wave/swash. The internal structures 
of the prograding sedimentary bodies connected to the ridges are typical of coarse-grained reflective beaches in nontidal environments. The concave-up morphology of the prograding units is consistent with essentially fair-weather conditions, although we found evidence of storm activity in erosional surfaces separating sets of parallel laminae in the foreshore facies, and as parallel-laminated gravelly layers intercalated in the sandy shoreface facies.

Following Tanner's (1995) reasoning, the generation of beach ridges and swales under essentially fairweather conditions means that crests were deposited at alternatively high (the elevated beach ridge) and low (the lower beach ridge that is preserved as a swale) positions. A simple mechanism to explain why crests were deposited at variable elevations is an oscillating sea level. High sea levels produce high beach ridges, whereas comparatively lower sea levels produce topographically lower beach ridges, which are observed as swales (Tanner, 1995), as in the swale separating $\mathrm{H}_{3}$ and $\mathrm{H}_{4}$. A crucial role is played by changes in the runup of the swash of the incoming waves associated with oscillations in sea level of even a few decimetres.

This mechanism explains the more-or-less continuous, quasi-parallel prograding pattern in the coastal plain. However, aerial photographs show conspicuous erosional surfaces that truncate the smooth trend, meaning that there is at least another process involved. Following Thompson and Baedke's (1995) findings, we interpret these surfaces to represent erosion, related to rises of sea level, which tends to destroy the beach ridges deposited during previous lower sealevel conditions. This has been demonstrated in Lake Michigan, where the shorelines reacted in response to quasi-periodic lake-level events producing either progradation or erosion (Thompson and Baedke, 1995).

\subsection{Age of beach-ridge units}

Using the detailed map of the described units, we selected several sites for samples with a double aim: (i) evaluating the age of units distinguished in the coastal plain, and (ii) calculating rates of growth of beach ridges. To do this, we assumed that ${ }^{14} \mathrm{C}$ dating of samples collected across the prograding complex (Table 1) permits calculation of time spans necessary for deposition, provided that the results are logical according with the stratigraphic and morpho-sedimentary patterns, given problems set by shell reworking in coastal environments.

Radiocarbon dating was performed on shells of the mollusc Glycymeris glycymeris. The only exception is sample UQ-1114 (Cerithium shell, Table 1). We collected nonfragmented shells in trenches where the 3-D stratigraphic architecture of deposits could be clearly established. Samples were taken preferably from the plunge-step facies of the lower foreshore, where the big shells tend to be more frequent. Results from shells collected on the surface of the coastal plain proved inconsistent because of reworking, therefore they were not taken into account for calculations. Conventional Radiocarbon Ages (CRA) cited in the text are calibrated using version 3.0 of the CALIB Program software (Stuiver and Reimer, 1993). Sanlaville et al. (1997) proposed a value of 400 years for the reservoir effect in the Mediterranean, very close to the 402-year figure given by Stuiver and Braziunas (1993), which is currently incorporated in our calibration software.

The age of $\mathrm{H}_{1}$ deduced from shells collected in trenches is ca. $7400-6000 \mathrm{cal} \mathrm{BP}$. The first figure is the oldest date obtained in the prograding complex. The upper limit represents a minimum age, and was selected according to the youngest data encountered, but it could be still younger. The age of $\mathrm{H}_{2}$ is $5400-$ $4200 \mathrm{cal}$ BP. The fossiliferous record in the palaeolagoon deposits that occur in the inner shores of Las Marinas lagoon Cerithium shells that were used for radiometric dating (sample UQ-1114, Table 1). Considering radiometric data, the age of Unit $\mathrm{H}_{3}$ extends from 4200 to $3000 \mathrm{cal} \mathrm{BP}$, but the erosional event eliminated the sedimentary record of the time span $3885-3155 \mathrm{cal} \mathrm{BP}$, leaving a hiatus that lasts for 730 years. Unit $\mathrm{H}_{4}$ was formed between 2700 and 1900 cal BP. Prominent erosion occurred across this boundary in the southern sector at ca. $2700 \mathrm{cal} \mathrm{BP}$. Unit $\mathrm{H}_{5}$ was deposited between 1900 and $1100 \mathrm{cal}$ BP. The first two sets are topographically more elevated than the rest and, according to ridge counting, they represent an interval of ca. 100 years.

The only accurate data available for dating Unit $\mathrm{H}_{6}$ refers to the closing of the Guardias Viejas lagoon after $1854 \mathrm{AD}$ (LHM, 1983) and the beginning of the protuberance of the Adra delta in 1871 AD (Goy and Zazo, 1986). Other data from this progradation phase 
can be gathered from nearby areas. In Cabo de Gata (Fig. 1), this unit is represented only in the southern closing of the lagoon and the present-day beach, with no precise age dating (Goy et al., 1998). In Calahonda (50 $\mathrm{km}$ to the West of Guardias Viejas), the accumulation of a well-preserved morpho-sedimentary unit equivalent to Unit $\mathrm{H}_{6}$ which began at ca. $500 \mathrm{cal} \mathrm{BP}$ (1450 AD), (Lario et al, 1999).

Maximum rates of progradation in the study area can be measured in a SW-NE direction, from the eastern margin of El Cerrillo lagoon to the southern limits of Roquetas. This includes Units $\mathrm{H}_{1}$ to $\mathrm{H}_{5}$, with mean rates of $1 \mathrm{~m} /$ year. Regarding $\mathrm{H}_{6}$, there is record of progradation in Punta Sabinal and Guardias Viejas, where the minimum rate for the preserved part can be estimated as $0.6 \mathrm{~m} / \mathrm{year}$. In most of the other coastal areas around Campo de Dalías, this period is essentially erosional.

\subsection{Changing coastal dynamics during progradation of beach-ridge systems: sea-level changes and climate}

The internal structure of the Roquetas coastal plain, also observed in plan view (Fig, 3), reflects the superimposition of two types of processes: (i) fluctuations of sea level that caused the morphological and topographic differences of the beach-ridge sets and units. (ii) Changes in the coastal dynamics that promoted dramatic changes in the progradation trends and rates of coastal growth (Fig. 5).

The prograding beach-ridge complex records the highstand of the fourth-order depositional sequence that began following the last glacial. Progradation of the coastal plain commenced at ca. $7400 \mathrm{cal} \mathrm{BP}$. This is the time of maximum flooding in the southern coast of Spain (Goy et al, 1986a; Zazo et al., 1994; Somoza et al., 1998; Dabrio et al, 2000). Highstand conditions have persisted since then, but minor eustatic fluctuations have influenced the deposition of the beachridge complex. We have deduced the values of these fluctuations from the relative elevations of present ridges as related to MSL. At present, the active fairweather beach crests (beach ridges in case of preservation) in Punta Sabinal rise to $0.7-0.8 \mathrm{~m}$ above MSL. Using this reference, we estimated values of "MSL" for the H-units, allowing the minor oscillations required for depositing successive ridges and swales. In summary, our estimations are: beach ridges of $\mathrm{H}_{1}$ are degraded preventing accurate calculations $\mathrm{MSL}_{3}$ but it was lower than at the beginning of $\mathrm{H}_{2}$ (Fig. 6).

MSL during deposition of the swale separating $\mathrm{H}_{2}$ and $\mathrm{H}_{2}$, was -0.4 to $-0.5 \mathrm{~m}$. MSL in early $\mathrm{H}_{2}$ was about +0.6 to +0.8 , but it fell afterwards to +0.3 to $+0.4 \mathrm{~m}$ and remained more or less in these values during most of units $\mathrm{H}_{2}$ and $\mathrm{H}_{3}$. The erosional episode ca. $3155 \mathrm{cal} \mathrm{BP}$ is interpreted as a rise of sea level above the mentioned values that was not compensated by sediment input and thus destroyed beach ridges up to $1 \mathrm{~m}$ above MSL. As it did not leave behind large, high beach ridges, we assume that the additional positive oscillation did not exceed $+0.5 \mathrm{~m}$.

The swale separating $\mathrm{H}_{3}$ and $\mathrm{H}_{4}$, with a topographic elevation roughly at present MSL, records a new fall of sea level to values close to present. The height of beach ridges increased during the deposition of $\mathrm{H}_{4}$, following a rise of sea level from +0.3 to +0.5 $m$ in MSL.

The boundary $\mathrm{H}_{4}-\mathrm{H}_{5}$ records a rise of sea level that caused erosional transgression. Considering the elevation of the two first beach ridges, MSL rose temporarily (ca. 100 years) up to $0.8 \mathrm{~m}$ (perhaps more), to fall again through $\mathrm{H}_{5}$ to values close to those measured in $\mathrm{H}_{3}$ and $\mathrm{H}_{4}$ (ca. $+0.3 \mathrm{~m}$ ).

The poor record of $\mathrm{H}_{6}$ does not favour calculations, but our best guess is that MSL did not depart appreciably from its present values.

Set configurations A or B are related (at least partially) to sea level. In general, configuration A occurs following the episodes of highest sea level recorded in the area.

Let us consider now the effects of changing coastal dynamics. According to our reconstructions (Fig, 5), the coastline formed cuspate beaches during a large part of the recent depositional history $\left(\mathrm{H}_{1}\right.$ to $\mathrm{H}_{3}$, i.e., $7400-3000 \mathrm{cal} \mathrm{BP}$ ) that record balanced littoral drifts under easterly and westerly winds. We assume this as proof of relatively weak westerly winds and Atlantic Surface Water inflow over the time, which magnified the relative importance of the drift pushed by easterly winds. Westward-moving waves induced by these persistent winds reached obliquely the coast of Roquetas and played a major role in this process. Erosion of the tectonically raised last interglacial coarse beach deposits supplied a wealth of sediment to the coastal zone that was moved to the SW and 


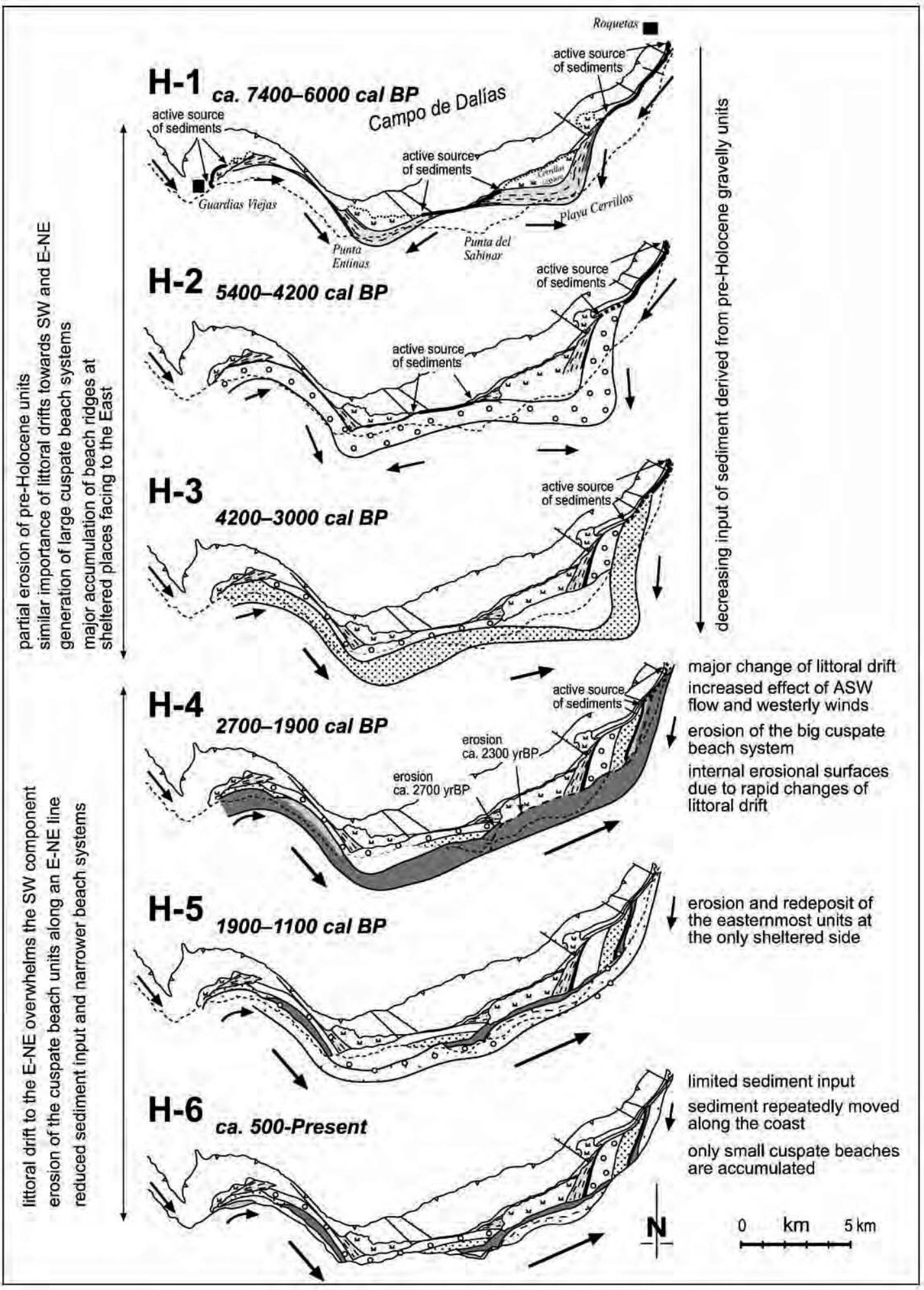




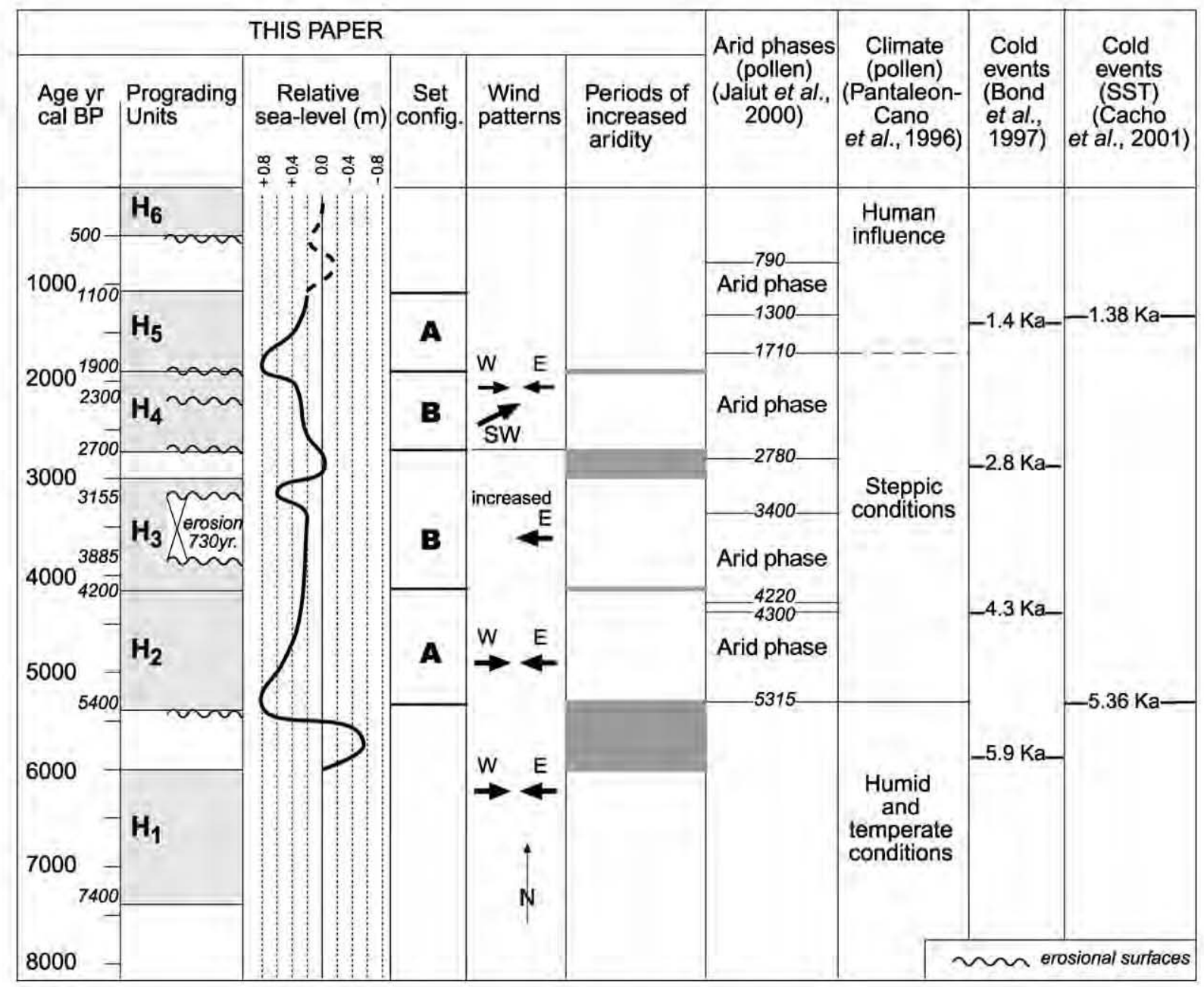

Fig. 6. Chronostratigraphy of prograding phases, estimated mean sea levels, wind and climate trends and quasi-millennial cycles in Almería. Arid phases after Jalut et al. (2000) with cal BP ages transformed to $1 \sigma$, climates after Pantaleón-Cano et al. (1996), and human influence after Burjachs et al. (1997). North Atlantic Holocene cold events by Bond et al. (1997). Sea Surficial Temperature (SST) cold events deduced from the core MD95-2043 in Alborán Sea (Cacho et al., 2001). The value of relative "MSL" for a given H-unit is an average of the small fluctuations needed to deposit successive ridges and swales.

incorporated into the large cuspate beaches. However, the decreasing length of the cliff exposed to erosion must have resulted in a continuous reduction of sediment input to the eastern Campo de Dalías, as compared with the more continuous input from the Adra river mouth. The sheltering effect of the hilly Campo de Dalías headland favoured the trapping of sediments. The headland also protected them from erosion by the eastwards-moving currents driven by westerly winds (plus the imperfectly known effects of the Atlantic Surface Water gyre).

In our opinion, the higher, wider beach ridges of configuration " $\mathrm{A}$ " require larger sediment inputs and higher relative sea levels than those of configuration

Fig. 5. Proposed coastal evolution of the southern Campo de Dalías illustrating successive coastal encroachment and erosion, related to changing dynamic conditions. 
" $\mathrm{B}$ ". Both factors explain the change from configuration " $\mathrm{A}$ " $\left(\mathrm{H}_{2}\right)$ to "B" $\left(\mathrm{H}_{3}\right)$.

Unit $\mathrm{H}_{4}$ was deposited between 2700 and $1900 \mathrm{cal}$ $\mathrm{BP}$, and during this time span the coastal response identifies a dramatic change in forcing conditions, when the eastward-directed components overwhelmed the SW drift. A result was the erosion of the cuspate beaches along an E-NE line ca. $2700 \mathrm{cal} \mathrm{BP}$. This was probably enhanced by the end of erosion in the cliff in eastern Campo de Dalias that dramatically reduced the input of sediment to the coast. The major change of littoral drift suggests increased southwesterly winds as compared with westerly and easterly winds. Another well-recorded erosional event took place ca. $2300 \mathrm{cal}$ BP near Cerrillos beach.

Changes in coastal dynamics ca. $2700 \mathrm{cal} \mathrm{BP}$ have been reported in other sites in southern Spain. Goy et al. (1998) found that Holocene aeolian accumulations began in Cabo de Gata ca. 2700 cal BP, under winds from the SW. Borja et al. (1999) showed that accumulation of Holocene aeolian dunes in the Gulf of Cadiz commenced ca. $2700 \mathrm{cal} \mathrm{BP}$, under prevailing winds from the W-SW. Pollen records in the Western Mediterranean register the beginning of an arid phase at $2780 \mathrm{cal} \mathrm{BP}$ (Jalut et al, 2000).

Units $\mathrm{H}_{4}$ and $\mathrm{H}_{5}$ are separated by an erosional surface that eliminated the foreshore facies deposited during the relatively lower MSL that gave place to the swale.

The first two sets of Unit $\mathrm{H}_{5}$ are topographically more elevated than the rest, but the associated foreshores facies rest upon the more distal shoreface facies of Unit $\mathrm{H}_{4}$. This seems to indicate a short-lived (about one century) rise of sea level, and may have been favoured by a temporary increase in the frequency and velocity of easterly winds that piled up water against the coast of Roquetas, and magnified the runup of waves. It was followed by a gradual sea-level fall of approximately $0.5 \mathrm{~m}$.

$\mathrm{H}_{6}$ is separated from all the $\mathrm{H}_{5}$ by an erosional surface that registers renewed changes in littoral drift and scarce sediment input. There is only a very poor record of this unit and this seems to be related to reduced sediment input to the coast.

The described evolution took place in a climatic framework that can be better understood by incorporating data yielded by SST and pollen studies in our study area (Fig, 6). Cacho et al. (2001) have studied the evolution of alkenone SST in the Alborán Sea (core MD95-2043, see Fig. 1) observing a general cooling trend during the Holocene which is punctuated by periodic short-lived cooling oscillations. Restricting ourselves to the time span covered by our study, one of these (at $5.36 \mathrm{ka}$ ) coincided with the beginning of $\mathrm{H}_{2}$, and another (at $1.38 \mathrm{ka}$ ) took place near the end of $\mathrm{H}_{5}$.

Pollen data in the coast of Almería indicate a sudden change of the vegetal cover as the climate evolved from humid to steppe conditions ca. 5400 cal BP (PantaleónCano et al., 1996; Jalut et al,, 2000), which coincides with the beginning of $\mathrm{H}_{2}$. From this time onwards, Jalut et al. (2000) distinguished four arid phases separated by shorter periods with less aridity (see dates in Fig. 6). These data seem to indicate that the arid phases coincide with progradation of $\mathrm{H}$-units. However, our data suggest that the situation is the reverse: the more arid episodes must represent reduced sediment inputs (and lower relative sea levels) at the boundaries of $\mathrm{H}$-units. Concerning sea level, there is general agreement in the occurrence of maximum flooding at ca. $7000 \mathrm{cal} \mathrm{BP}$, coinciding with the beginning of the present highstand in the southern Iberian Peninsula.

Proof of relative sea-level changes in our area was found by Hernández-Molina et al. (1995, in press) as an apron-shaped, sandy body with sigmoid-oblique seismic internal pattern, deposited between the beach and the inner continental shelf after ca. 6500 years BP. The internal structure of this body shows two progradational seismic units separated by an episode of higher sea level. It is tempting to compare this twofold pattern with the two distinct configurations in the coastal plain of Roquetas, but the lack of radiometric dating in the inner shelf reduces the accuracy of correlation. The change of configuration records a major change in the dynamics of the nearshore zone and the beginning of aeolian-dune accumulations in coastal areas nearby, ca. 2700 years BP (Goy et al., 1986a, 1998; Borja et al., 1999; Dabrio et al., 2000). This, however, is only a part of the story and there must be oscillations of shorter periods that account for the repeated generation of $\mathrm{H}$-units.

We suggest that the forcing factor behind these changes is the increased persistence of westerly winds during the relatively less-arid phases, which contributes to magnify the incursion of SAW into the Mediterranean and promotes local rises of sea level 
in southern Spain, with SST relatively high. In contrast, less effective westerly winds during the more arid phases reduce the incursion of SAW, and sea level remains essentially lower, with cooler SST. These episodes are shorter-lived.

\subsection{Periodicity of prograding beach ridges}

Considering the age of $\mathrm{H}$-units and the number of beach-ridge sets in each unit, it is possible to estimate the time required to deposit a couplet. Periodicity can be revealed comparing the results of various crosssections.

After disregarding the obviously reworked samples, it was possible to count the number of beach ridges in two intervals (note in Fig. 3 that some samples have been collected from vertical sections of the same trench). The first interval is limited by samples GX-22230 (4960 cal BP) and UQ-1135 ( 4065 cal BP), i.e., 895 years with 80 beach ridges (Fig. 3). The second interval is encompassed by samples Lv-R-2 (1910 cal BP) and the cluster GX21796 (1510 cal BP), GX-22227 (1500 cal BP), and GX-22228 (1530 cal BP), i.e., an average 400 years with 36 beach ridges (Fig. 3 ). A simple division gives values of 11.25 years to deposit a ridge and swale unit, 22.5 years to deposit a couplet, and 45 years to form a set of beach ridges (Fig. 4). Thus, both the morphology and the chronology of the prograding beach-ridge and swale system reveal that sedimentation followed a periodical pattern with decadal periodicities: $11.25,22.5$, and 45 years (Fig. 4).

Set counting reveals a centennial periodicity $(800 /$ 600 years) during the younger phases of progradation $\left(\mathrm{H}_{4}\right.$ and $\left.\mathrm{H}_{5}\right)$, and a millennial periodicity $(1400 / 1200$ years) during the three first prograding phases $\left(\mathrm{H}_{1}\right.$, $\mathrm{H}_{2}$, and $\mathrm{H}_{3}$ ). The short-term periodicity observed in the beach ridges, both morphologically and chronologically, must be linked to forcing factors at the decadal scale.

We think that the NAO index oscillations and the sunspot oscillations are suitable candidates. Smallscale changes of sea level are enhanced by water setup under prevailing winds, but this is a shorterlived process that falls in the monthly or yearly scale. It may be, perhaps, an indication of longer-lasting periods of increased wind setup, necessarily related to regional climatic patterns and trends.
Rodríguez-Ramírez et al. (2000) studied beach ridges and swales formed between 1961 and 1996 in spit bars of the Atlantic Gulf of Cadiz (SW Spain). To explain the genesis, they compared (i) the record of cyclone activity in relation to the speed and mean annual frequency of third-quadrant wind in autumn/ winter, (ii) mean annual values of the NAO index, and (iii) mean annual values for the sunspot oscillations. They establish that the generation of ridges follows a periodicity of 3-7 years related to negative values of the NAO index, and another around $10-12$ years that can be related to periods with less sunspot activity and which produces the more conspicuous ridges.

The evolution of MSL has been related to the fluctuations of the NAO index in the coasts of Portugal using the instrumental record of tide gauges of the chronological period 1882-1991 (Guerra et al،, 2000). The main conclusion of this paper is that there is an inverse correlation between MSL and NAO index: negative values of NAO correlate well with high sea levels.

The possible influence of NAO on the circulation of the Western Mediterranean Sea has been pointed out by Vignudelli et al. (1999). According to them, negative values of NAO intensify the heat losses to the atmosphere that increase water transport through the Corsica Channel.

The regularity of progradation in Roquetas suggests that the decadal periodicity $(11.25,22.5$, and 45 years) may be related to solar activity fluctuations, The basic 11-year cycle, the 22-year Hale cycle and the 45-year Double Hale cycle (Fairbridge and Hillaire-Marcel, 1977) coincide in our case with the deposition of a beach ridge and swale, a couplet and a set of beach ridges, respectively (Fig. 4).

In detail, a beach ridge is deposited during the negative phase of the NAO because this situation favours stronger winds from the SW and a sudden relative rise of sea level. The adjacent swale is generated during the positive phase of $\mathrm{NAO}$, under weaker SW winds and a relative fall of sea level.

Moving to the millennial periodicity, we correlate the short, more arid periods separating the $\mathrm{H}$-units in Roquetas between ca. 6.0 and $5.4 \mathrm{ka}\left(\mathrm{H}_{1}-\mathrm{H}_{2}\right)$, at ca. $4.2 \mathrm{ka}\left(\mathrm{H}_{2}-\mathrm{H}_{3}\right)$, between 3.0 and $2.7 \mathrm{ka}\left(\mathrm{H}_{3}-\mathrm{H}_{4}\right)$, at $1.9 \mathrm{ka}\left(\mathrm{H}_{4}-\mathrm{H}_{5}\right)$ with: (i) the short cold events dated by Bond et al. (1997) in the North Atlantic at ca. 5.9, $4.3,2.8$ and, probably, one at ca. $1.4 \mathrm{ka}$; and (ii) the 
short cold events of SST reported by Cacho et al. (2001) in the Alborán Sea (core MD95-2043) at 5.3 and $1.38 \mathrm{ka}$. Therefore, the short, cold events are recorded on land (at the coast) by short periods of increased aridity inside the general arid trend, with lower relative sea levels and reduced progradation rates.

\section{Conclusions}

The beach ridges in the Roquetas coastal plain were formed by wave/swash under essentially fairweather conditions. Alternating beach ridges and swales are formed in response to oscillating sea levels. Higher sea levels produce ridges, whereas comparatively lower sea levels produce topographically lower beach ridges, which are observed as swales.

Ridges that record beach progradation occur as couplets separated by a narrow intervening depression or swale. Adjacent couplets are separated by slightly wider swales. In turn, pairs of couplets are separated by still wider swales. The four-ridge pattern is called a "set" of beach ridges. According to the magnitude (width and height) of crests and the width of swales that form the sets, it is possible to distinguish two configurations of sets (A and B). Crests in sets of configuration $\mathrm{A}$ tend to be higher and better separated and the swales become wider in a southward direction, whereas in sets of configuration $\mathrm{B}$, the size and trend is more homogeneous. Sets of configuration A are interpreted to indicate higher relative sea levels and more sediment input than those with configuration B.

Morpho-sedimentary features and radiocarbon dating allow to separate six prograding units (named $\mathrm{H}_{1}$ to $\mathrm{H}_{6}$ ) composed of groups (bundles) of sets distinguished from adjacent units by changes of set configuration, large swales or erosional surfaces. The ages of H-units are: $\mathrm{H}_{1}$, ca. 7.4-6.0 ka; $\mathrm{H}_{2}, 5.4-4.2 \mathrm{ka}$; $\mathrm{H}_{3}, 4.2-3.0 \mathrm{ka} ; \mathrm{H}_{4}, 2.7-1.9 \mathrm{ka} ; \mathrm{H}_{5}, 1.9-1.1 \mathrm{ka} ; \mathrm{H}_{6}$, ca. $0.5 \mathrm{ka}$ to present.

At least since the beginning of $\mathrm{H}_{2}, \mathrm{H}$-units correlate well with arid periods with comparatively high sea levels, increased sediment input to the coast, increased intrusion of Atlantic Superficial Water (ASW), and stronger W-SW winds. In contrast, the boundaries of $\mathrm{H}$-units correspond to periods of increased aridity with relatively lower sea level, reduced sediment input, reduced intrusion of ASW and weaker W-SW winds. Estimated changes of relative MSL during the Holocene do not exceed 1.3 m.

A major change of littoral drift is observed at ca. $2.7 \mathrm{ka}$, in the limit $\mathrm{H}_{3}-\mathrm{H}_{4}$, when the action of W-SW winds increased as compared with the easterlies. The regularity of progradation in Roquetas suggests a decadal periodicity for the deposition of a beach ridge and the adjacent swale that we suggest is related with variations of solar activity and with fluctuations of the North Atlantic Oscillation (NAO) index.

The duration of $\mathrm{H}$-units suggests a quasi-millenmial periodicity of the occurrence of short periods of increased aridity that seem to coincide with the short cold events in the North Atlantic pointed out by Bond et al. (1997) and, in some cases, with the SST events recorded by Cacho et al. (2001) off the coast of Almería,

\section{Acknowledgements}

Dr. Javier Lario assisted in the calibration software. José Baena (deceased), Francisco González-Hernández, Luis Luque and Dr. Isidro de Villota provided invaluable field assistance. We gratefully acknowledge the careful review by Dr. Roland Gehrels and an anonymous referee. Financial support from Spanish Dirección General de Enseñanza Superior (DGES) Projects PB98-0265 and PB98-0514. This is a contribution to IGCP Project 437 (Coastal environmental change during sea-level highstands) and to the INQUA Sea Level Change and Neotectonic Commission.

\section{References}

Anonymous, 1976. Plano indicativo de usos (PIDU) del dominio litoral. Provincia de Murcia Servicio de Publicaciones Ministerio de Obras Públicas y Urbanismo, Madrid. $93 \mathrm{pp.}$

Baena, J., García-Rodríguez, J., Maldonado, A., Uchupi, E., Udías, A., Wandossell, J., 1982. Mapa geológico de la plataforma continental española y zonas adyacentes 1:200,000 Almería-Garrucha (84-85). Chella-Los Genoveses $(845-855)$. ITGE. Servicio de Publicaciones Ministerio de Industria y Energía. 105 pp.

Bond, G., Showers, W., Cheseby, M., Lotti, R., Almasi, P., de Menocal, P., Priore, P., Cullen, H., Hajdas, I., Bonani, G., 1997. A 
pervasive millennial-scale cycle in North Atlantic Holocene and glacial climates. Science 278, 1257-1266.

Borja, F., Zazo, C., Dabrio, C.J., DíazDel Olmo, F, Goy, J.L., Lario, J, 1999. Holocene aeolian phases and human settlements along the Atlantic coast of Southem Spain. Holocene 9.3, 333-339.

Burjachs, F, Giralt, S., Roca, J.R., Juliâ, R, 1997. Palinología holocénica y desertización en el Mediterráneo Occidental. In: Tbáñez, J.L.y Valero Garcés, L., Machado, C. (Eds.), El paisaje mediterráneo a través del espacio y del tiempo. Implicaciones en la desertización. Geoforma Ediciones, Logroño, pp, 379-394.

Cacho, I., Grimalt, J.O., Canals, M., Shackleton, N., Schönfeld, J., Zahn, R., 2001. Variability of the Western Mediterranean Sea surface temperature during the last 25,000 years and its connection with the Northern Hemisphere climatic changes. Paleoceanography $16,40-52$.

Dabrio, C.J., Zazo, C., Goy, J.L., Sierro, F.J., Borja, F., Lario, J., González, J.A., Flores, J.A, 2000. Depositional history of estuarine infill during the last postglacial transgression (Gulf of Cádiz, southern Spain). Mar. Geol. 162, 381-404.

Fairbridge, R.W., Hillaire-Marcel, C., 1977. An 8000-yr palaeoclimatic record of the "Double-Hale" 45-yt solar cycle. Nature $268,413-416$.

Goy, J.L., Zazo, C., 1986. Western Almería (Spain) coastline changes since the last interglacial. J, Coastal Res. 1, 89-93.

Goy, JL., Zazo, C., Dabrio, C.J., Hillaire-Marcel, C, 1986a. Evolution des systemes de lagoons-iles barriere du Tyrrenien a l'actualité a Campo de Dalías (Almería, Espagne). I.F.R.S. Trav, Doc. 197, 169-171.

Goy, J.L., Zazo, C., Hillaire-Marcel, C., Causse, Ch., 1986b. Stratigraphie et chronologie (U/Th) du Tyrrhênien du Sud-Est de l'Espagne. Z. Geomorphol. 62, 71-82.

Goy, J.L., Zazo, C., Dabrio, C.J., Baena, J., Harvey, A.M., Silva, P., González, F., Lario, J., 1998. Sea level and climate changes in the Cabo de Gata lagoon (Almería) during the last 6500 yr BP. (INQUA), Subcommission on Mediterranean and Black Sea Shorelines (MBSS) Newsletter 20, 11-18.

Guerra, S.A., Pires, H.O., Taborda, R.P., 2000. O nivel medio do mar, a oscilação do Atlantico Norte e a variabilidade climática em Portugal. Extended Abstracts, 3rd Symposium on the Iberian Atlantic Margin, Faro (Portugal), 351-352.

Herburn, G.H., la Violette, P.E, 1990. Variations in the structure of the anticyclone gyres found in the Alborán Sea. J. Geophys. Res. C.2, 1599-1613.

Hernảndez-Molina, F.J., Somoza, L, Vázquez, J.T., Rey, J, 1995. Estructuración de los prismas litorales del Cabo de Gata; respuesta a los cambios climáticos-eustáticos holocenos. Geogaceta $18,79-82$.

Hernández-Molina, F.J., Fernández-Salas, L.M., Lobo, F., Somoza, L., Díaz-del Río, V., Alveirinho Dias, IM., in press. The infralittoral prograding wedge: a new large-scale progradational sedimentary body in shallow marine environments. Geomarine Lett.

Hurrell, J.W., 1996. Influence of variarions in extratropical wintertime teleconnections on Northern Hemisphere temperature. Geophys. Res. Lett. 23, 665-668.

IHM-Instituto Hidrográfico de la Marina, 1983. Derrotero de las Costas del Mediterrâneo. Servicio de Publicaciones de la Armada, Madrí, pp. 102-114.
Jalut, G., Amat, A.E., Bonnet, L., Gauguelin, Th., Fontugne, M., 2000. Holocene climatic changes in the western Mediterranean, from south-east France to south-east Spain. Palaeogeogr. Palaeoclimatol. Palaenecol. 160, 255-290.

Lario, J., Zazo, C., Goy, J.L., 1999. Fases de progradación y evolución morfosedimentaria de la flecha litoral de Calahonda (Granada) durante el Holoceno. Estud. Geol. $55(5-6), 247=250$.

Otvos, E.G., 2000. Beach ridges-definitions and significance. Geomorphology 32, 83-108.

Pantaleón-Cano, J., Yll, E.I., Pérez-Obiol, R., Roure, J.M., 1996. Las concentraciones polínicas en medios semiáridos. Su importancia en la interpretación de la evolución del paisaje. In: Ramil-Rego, P., Fernández Rodríguez, C., Rodriguez. Guitian, M. (Eds.), Biogeografia Pleistocena-Holocena de la Península Toérica. Xunta de Galicia, Santiago de Compostela, pp. $215-226$.

Rodríguez-Ramírez, A, Cáceres, L., Rodríguez-Vidal, J., Cantano, M,, 2000. Relación entre clima y génesis de crestas/surcos de playa en los últimos cuarenta años (Huelva, Golfo de Cádiz). Rev. Cuat. Geomorfol. 14, 109-113.

Sanlaville, P., Dalongeville, R., Bernier, P., Evin, J., 1997. The Syrian coast: a model of Holocene coastal evolution. J. Coastal Res. $13(2), 385-396$.

Sarachik, E.S., Alverson, K., 2000. Opportunities for CLIVAR/PAGES NAO. Studies Pages Newletter 8-1-Clivar Exchanges 5-1, $14-16$.

Somoza, L., Barnolas, A., Arasa, A., Maestro, A., Rees, J.G., Hernandez-Molina, FJ., 1998. Architectural stacking patterns of the Ebro delta controlled by Holocene high-frequency eustatic fluctuations, delta lobe switching and subsidence processes. Sediment. Geol. 117, 11-32.

Stuiver, M., Braziunas, P., 1993. ${ }^{14} \mathrm{C}$ ages of marine samples to 10,000 BC yr BP. Radiocarbon 35 (1), 137-189.

Stuiver, M, Reimer, P., 1993. Extended ${ }^{14} \mathrm{C}$ data base and revised CALIB $3,0^{14} \mathrm{C}$ calibration program. Radiocarbon 35 . 231-237.

Tanner, W.F, 1995. Origin of beach ridges and swales. Mar. Geol. $129,149-161$.

Targanona, J., Alonso, B., Canals, M., Rohling, E., Versteegh, G., 1997. Productivity variations in the Alborán Sea over the last 20,000 years from Protoperidinium dinoflagellate cysts records. In: Targarona, J. (Ed.), Climatic and Oceanographic Evolution of the Mediterranean Region Over the Last Glacial-Interglacial Transition. LPP Contributions Series, vol. 7. LPP Foundation, Utrecht, The Netherlands; pp. 44-66.

Thompson, T.A., Baedke, S.J., 1995. Beach-ridge development in Lake Michigan: shorelines behaviour in response to quasi-periodic lake-level events. Mar. Geol. 129, 163-174.

Vignudelli, S., Gasparini, G.P., Astraldi, M., Schiano, M.E, 1999. A possible influence of the North Atlantic Oscillation on the circulation of the Western Mediterranean Sea. Geophys. Res. Lett. $26(5), 623-626$.

Zazo, C., Goy, J.L., Somoza, L., Dabrio, C.J., Belluomini, G., Improta, J., Lario, J., Bardají, T., Silva, P.G., 1994. Holocene sequence of sea-level fluctuations in relation to climatic trends in the Atlantic-Mediterranean linkage coast. J. Coastal Res. 10, $933=945$. 
Zazo, C., Dabrio, C.J., Goy, J.L., Bardaji, T., Ghaleb, B., Lario, J., Hoyos, M., Hillaire-Marcel, F, Sierro, F., Flores, J.A., Silva, P.G., Borja, F, 1996. Cambios en la dinămica litoral y nivel del mar durante el Holoceno en el Sur de Iheria y Canarias Orientales. Geogaceta $20(7), 1679-1682$.

Zażo, C., Bardaji, T., Dabrio, C.I., Goy, J.L., Hillaire-Marcel, C.,
1998. Field trip A7. Record of Late Pleistocene and Quaternary sea-level changes in coastal settings, southeast Spain. In: Meléndez-Hevia, A., Soria, A.R. (Eds.), Field Trip Gúidebook, 15th International Sedimentological Congress. Instituto Teenológico y Geominero de España, Madrid, pp. 149-169. 